\title{
WAITING FOR THE ADOPTION OF THE DRAFT CIVIL CODE OF THE REPUBLIC OF SERBIA (IMPORTANT FOR THE LAW REGULATION OF THE FRANCHISING AGREEMENT)
}

\author{
Strahinja D. MILJKOVIĆ \\ Associate Professor \\ University of Priština in Kosovska Mitrovica, \\ Faculty of Law \\ E-mail: strahinja.miljkovic@pr.ac.rs \\ Igor SIMIĆ \\ Assistant Professor \\ University of Priština in Kosovska Mitrovica, \\ Faculty of Economics \\ E-mail:igor.simic@pr.ac.rs
}

\begin{abstract}
In 2006, the Commission for drafting the Civil Code of the Republic of Serbia was established. The first book of the Civil Code was completed and made available to the public in 2007. To the present, not much progress has been made in the effort to adopt and enter into force the Civil Code, with primaly work being done developong amendments to the working versions. The working versions of the code envisage the regulation of a new and specific agreement, the franchise agreement. Listening to the needs of the market, as well as the need to introduce this type of business into legal frameworks, the editors of the Civil Code (now the Draft Civil Code-DCC) for the first time legally standardise a franchise agreement. It should be noted that legal standardisation of franchising agreements has significant advantages in terms of legal transactions and contracting parties. However, although there is are strong intentions, it should be noted that there are some shortcomings in the legal standardisation of the franchising agreement in the Serbian document. Shortcomings are observed in the standardisation of the franchising agreement, especially in circumstances where the franchising agreement is unknown to much of the legal theory, business and case law of the Republic of Serbia. This creates the feeling that this business was approached in a superficial manner without a deeper analytical approach,
\end{abstract}


looking at solutions provided in the legal acts and case law of countries with developed franchising business. The shortcomings of the DCC of the Republic of Serbia are in the part related to legal standardisation of franchising agreements that could be brought to the attention of: a) the concept of contracting parties; b) the subject matter of the agreement; c) specific obligations (e.g. obligation of the franchisee to apply the business concept of franchise network in an independent business); d) use of legal implants without explaining their content (e.g. goodwill), etc. The author will point out the shortcomings of legal standardisation of the franchise agreement in the DCC and the possible solutions.

Keywords: Draft Civil Code of Serbia, franchising, franchisor, franchisee, franchising agreement, regulation, registration, subfranchising, transferred rights, pre-contractual disclosure, goodwill.

\section{Introductory Notes}

Contemporary market movements and the need of capital to conquer new markets through minimum investments undoubtedly affect to a significant extent the development of contemporary autonomous business operations of commercial law. One of a series of business operations that are the product of movements in the market of goods and capital is a business franchise and, consequently, the agreement as an instrument of implementation thereof. The etymology of the term franchising has its source in the old French word la franchise (Zlatković, 1999, p. 18). Franchise was a name for an agreement concluded between the king and the city guaranteeing the city council the right to govern within its activities, and the city with such privileges is known as the Villa Franche (Sautereau, 1992, p. 107).

Franchising as a business concept in evolutionary development has gone through a phase of: a) traditional and b) integral concept (Jović, 1990, p. 4). The integral concept, as a modern concept of franchising business, is based on the current business cooperation of the franchisor and recipient, which in addition to services, products, trademark, refers to the entire business, marketing strategies and plans, intellectual property rights, business control, know-how, goodwill and business methods. In addition to business cooperation, continuous personal communication of the contracting parties is another feature of the integral concept of franchising business. (Blair \& Lafontaine, 2005, p. 7).

Franchising as a method of contractual investment business is a distribution technique that integrates the distribution system by contract instead of the ownership chain managed from one centre (Emerson, 1990, p. 1508). As a specific investment method of contractual business operations, i.e. as a concept of contractual expansion of business operations in a target market, 
franchising is becoming ever more aggressively significant in the contemporary market circumstances. The reasons that are certainly identifiable and affect the expansion of business franchises are as ,need for successful business operations growth, and capability to achieve such growth by liaising with others that own capital and labour force for such a thing" (Mendelsohn, 2004, p. 1).

Franchising business enables the receiver of the franchisee to expand their business with minimum investments and minimum investment risks in the target market. The significance of franchising as an investment method lies in enabling the franchisee to access a developed franchising network by concluding an agreement. Having accessed a franchising network, the franchisee uses all the advantages of the franchisor's developed and tested-inpractice business operations system (Miljković, 2018, p. 43-55).

The production and distribution of goods, and also rendering or providing services at all levels in modern business and commercial operations are largely secured by franchising transactions. ${ }^{1}$ Franchising transactions in the contemporary circumstances of market business operations include manufacturers, wholesalers and retailers.

\section{Franchising in Republic of Serbia}

Though franchising has existed in the Republic of Serbia for many years, ${ }^{2}$ it has not been used as a business system to any considerable extent. The share of franchising in the market of the Republic of Serbia has been negligible

\footnotetext{
${ }^{1}$ In 2019, there were 773,603 franchise establishments in the United States. In 2019, the economic output of franchise establishments in the United States was about 787.5 billion U.S. dollars. Contributing to the economic output of franchise establishments in the United States, were about 8.43 million people who worked for a franchise business. (2021, September 25). Retrieved from https://www.statista.com/statistics/190313/estimated-number-of-us-franchiseestablishments-since-2007/; According to the records of the Fédération Française de la Franchise (FFF), in 2020 year, the number of franchise networks was 1,927, with turnover of EUR 63,88 billion. (2021, September 27). Retrieved from https://www.franchise-fff.com/franchise/les-chiffres-cles; Sales generated by the German franchising industry. Even in the crisis year of 2020, current franchise statistics indicate a positive development of the franchise economy. According to these statistics, approximately 930 franchise systems nationwide had a total of 138,748 franchise partners in the past year, an increase of $4 \%$ from the previous year. Overall, the $176,240(+2.6 \%)$ franchise operations employed approximately 749,198 employees, corresponding to an increase of $4.5 \%$. These figures attest to growth and ongoing development even in 2020, a year dominated by the Covid pandemic. This is reinforced by the development of total revenues: At 135 billion euros, this figure increased again by $4.6 \%$ compared to the previous year. (2021, September 27). Retrieved from https://en.franchiseverband.com/german-market

${ }^{2}$ Since 1970s, several American franchising systems have entered the market of SFRY, specifically: Coca Cola, Avis, Hertz, Diners Club International, Hyatt, American Express and McDonald's.
} 
until recently, while as of 2003 franchising as a business concept has begun to develop significantly, with a tendency of market expansion. The period since 2003 is characterised by the entry of major franchising systems in the fashion industry (Zara, Springfield, Mango, Oviesse) and sales of office supplies (Office 1 Superstore). Although 2003 is the year of entry of major foreign franchising systems into the market hungry for medium quality products, this period is also characterised by the development of local franchises. ${ }^{3}$ In $2006-$ 2007, the period of expansion of the real estate market in the Republic of Serbia, $\mathrm{Re} / \mathrm{Max}$ и Century 21 (the companies the business operations of which are based on franchising) made entry into the market.

At the end of 2020, there were 255 franchising systems operated in the Republic of Serbia, 163 or $64 \%$ part of the foreign franchising business systems and 92 franchising business systems or $36 \%$ belonged to the local franchising business systems. Out of the total number of franchise systems operating in Republic of Serbia, 127 - practically half - originate from the Central and Eastern European countries - CEE area (92 are from Republic of Serbia and 35 from other CEE countries). The remaining 128 systems originate from Western Europe, the United States or Asia. Observed by sectors, 148 franchising business systems operate in the field of services (58\%), and 107 (42\%) in the field of trade. There is a noticeable increase in the number of franchise brands in service activities as opposed to trade. ${ }^{4}$ Foreign franchises still dominate in the number of active systems in the Republic of Serbia. Of the foreign franchises, the largest number 35, originate from the United States. After the US system, the presence in the Serbian market, include the systems from France (17), Italy (14), Germany (10) and United Kingdom (8). In addition, systems from countries in the region are active in Serbia including ten franchises from Croatia and eight from Slovenia. Viewed by type of activity, foreign franchises in service sector, rather than in trade represent more of the R. Serbian market. ${ }^{5}$

\section{Legal Status of Franchising Agreements in the Republic of Serbia}

\subsection{Franchise Agreement Definition}

The only legal document in the Republic of Serbia currently providing the definition of franchising in its provisions is the Regulation no. 11/2010 (Regulation on Agreements between Market Participants Operating at

\footnotetext{
${ }^{3}$ Afrodite Mode Collection (fashion industry); DIS (retail and wholesale chains); ComTrade (computer equipment and software distribution); E-shop (online shopping portal); MiniMaxi (retail stores); Doughnut bar (fast food).

${ }_{4}$ (2021, September 27). Retrieved from https://franchising.rs/clanak/1698/trzistefransiza-u-srbiji-raste/

5 (2021, September 27). Retrieved from https://franchising.rs/clanak/1699/najvisefransiznih-sistema-sad/
} 
Different Levels of Production or Distribution which are Exempt from Prohibition, Official Gazette of the RS, no. 11/2010). Regulation no. 11/2010, defines franchising as an agreement whereby one party to the agreement (franchisor), for a fee, gives right to use intellectual property and know-how to another party to the agreement (franchisee) for the purpose of production and/or sales of the contracted product (Art. 3. para. 7). Though the indicated definition is currently the only valid definition of the franchising agreement within the legal frame in the Republic of Serbia, it has significant shortcomings. The first shortcoming refers to the fact that not only intellectual rights and know-how are assigned pursuant to the franchising agreement, but the franchisor also takes over the obligation to train and provide support in the field of administrative and marketing operations. The second shortcoming of the definition is reflected in the fact that it is based on agreements related to production and distribution of products only, while the agreements related to the field of services are not taken into account. However, despite these shortcomings, the definition represents a significant step forward in the formulation of franchising agreements in a legal document of the Republic of Serbia, even in a document such as the Regulation.

\subsection{Regulation of Franchise Agreement in the Republic of Serbia}

Unlike nominate contracts regulated by the law, franchise agreements are categorised in the legal system of the Republic of Serbia as innominate ones (not standardised by the law). The legal system of the Republic of Serbia does not recognise a legal document directly regulating the franchise agreement. Neither is there a direct legal regulation in the area representing the essence of each form of the franchise agreement, and relating to the precontractual disclosure of data - submission of a disclosure document.

The question is whether there is an indirect legal regulation of franchising agreements. When answering this question, one should be extremely careful because of lack of knowledge or low awareness concerning the law and judicial practice of franchising agreements. However, it should be noted that general legal principles of the contractual provisions of the Law of Contract and Torts (Law on Contract and Torts - LCT, Official Gazette of SFRY, no. 29/78, 39/85, 45/89 - Decision of the Constitutional Court of Yugoslavia and 57/89, Official Gazette of SFRY, no. 31/93, 22/99, 23/99, 35/99, 44/99 and Official Gazette of Serbia and Montenegro, no. 1/2003 Constitutional Charter) are directly applicable to the franchising agreement. It should also be noted that certain provisions of the license agreement and trade agency agreement (Mlikotin-Tomić, 1986, p. 155) regulated by the LCT are applicable to the franchising agreement. Analogue administration of the provisions regulating license agreement and trade agency agreement is justified by the attitude concerning the legal nature of the franchise agreement. It is argued that tense assimilation of a franchise agreement with a license agreement is possible. The indirect legal regulation of the franchising 
agreement is also possible by analogous application of provisions of the law used to standardise: a) trademark, b) industrial design and b) competition.

Based on the above, it is becoming increasingly common in the professional public of the Republic of Serbia to ask whether a legal document is required to regulate the franchising agreement. Proper answer to the question posed is of extreme importance, particularly in the segment referring to the fact of whether it is necessary to: a) standardise the franchise agreement within the Civil Code; a) pass a special law that would regulate the franchise agreement in a concise manner; b) pass a law that would regulate precontractual data disclosure only with contractual obligations being subject to the provisions of the LCT and Civil Law rules or c) pass and adopt amendments and addenda to the regulation of the existing laws that would regulate franchising directly. Regardless of the outcome in terms of solutions of the legal regulation of the franchising agreement, special attention in the further text is paid to the solutions stipulated by the Draft Civil Code of the Republic of Serbia - DCCRS. ${ }^{6}$

\section{Some of the Solutions Contained in the Draft Civil Code of the Republic of Serbia}

The work on the adoption of the DCCRS is characterised by stipulation of new: a) legal institutes and b) contracts categorised as innominate contracts. One of the innominate contracts that can be found in the DCCRS is the franchising agreement. Stipulation in the legal document such as Civil Code, even in the form of a Draft, is considered a significant milestone in terms of legal standardisation of the franchise agreement within the legal system of the Republic of Serbia.

Definition of the Agreement - Pursuant to the provisions of the DCCRS, the franchising agreement establishes ,the relationship of permanent cooperation between legally independent economic entities, whereby one contracting party - the franchisor undertakes, as the holder of the franchise business network, to transfer to another contracting party - the franchisee, the rights and provide services to include the franchisee in the franchisor's business system, and the franchisee undertakes to pay a direct or indirect fee for it. The franchisor transfers to the franchisee an exclusive right to sell goods or render services in a certain territory, right to use the franchisor's business name, intellectual property rights, right to use commercial, marketing and technical methods and know-how in business operations. The franchisor permanently provides training and business support services, as well as control and supervision of the franchisee's business operations to preserve the identity of the franchising network". (DCCRS, art. 1260). Though the editors have tried, by the indicated definition, to provide a comprehensive definition and

${ }^{6}$ Draft Civil Code of the Republic of Serbia - DCCRS. (2021, September 29). Retrieved from https://www.mpravde.gov.rs/files/NACRT.pdf 
avoid all shortcomings of the definition of the franchising agreement stipulated by the Regulation no. 11/2010, in our opinion it is far too broad, awkward, and confusing for a reader to understand the nature of the franchising agreement. The legal system that fails to recognise or has poorly developed law and judicial practice, and in which the franchising business remains within the scope of a statistical error, the work on adopting a comprehensive and substantive definition of the franchise agreement is a difficult task.

On the subject matter of the agreement - When establishing the subject matter of the franchising agreement, the editor decisively states that the subject matter of the agreement may be: a) exclusive right to sell goods or render services in a certain territory; b) right to use the business name of the franchisor, intellectual property rights, c) right to use commercial, marketing and technical methods and know-how in business operations.

We consider that although in the legal territory of the Republic of Serbia, which belongs to the ius civile system, there is no common position on a single - generic term to denote the subject matter of the franchising agreement, it is necessary to establish a single - generic term for the package of rights comprising the subject matter of the franchising agreement. The first reason this is important is the evolution of franchising business. The first generation of franchising is based on the concept of sales and distribution, and thus the subject matter of the agreement are goods or products only. The subject matter of the franchise agreement of the second generation, business format franchising, are not only the goods but also rights, services and business method as a package of rights. The package of rights includes: right to use the franchisor's trade name, and/or trade mark and/or srvice mark, know-how, business and technical methods, procedural system, and other industrial and/or intellectual property rights (European Code of Ethics for Franchising, art. 1). ${ }^{7}$ The second reason is that, no matter if they are agreements of classical or contemporary autonomous commercial law, they are characterised by a single term representing the subject matter of the agreement. The third reason is the fact that it is an agreement resulting from the contemporary business practice of market-developed countries. In the circumstances of striving towards market integration, it is necessary to accept the terminology that is recognisable to market participants. The term and notion of franchise is recognised by the market subjects as a term denoting the subject matter of the franchise agreement. The fourth reason is lack of properly created term in the Serbian language that would be used to denote the subject matter of the franchising agreement. However, the practice so far has proved that business operations coming from the legal system based on common law are implemented in their original terminological forms into the Serbian legislation. For the reasons stated

${ }^{7}$ European Code of Ethics for Franchising. (2021, September 29). Retrieved from https://franchising.eu/franchise-guide/26/the-european-code-of-ethics-for-franchising/ 
above, we support the position that the term „franchise" should be used for the subject matter of the agreement.

Although the reasons why the term franchise should be accepted as the term that would designate the subject matter of the franchise agreement have been justified, there are still different standpoints in the legal theory in the Republic of Serbia (Kapor \& Carić, 2000, p. 537-538). The primary and exclusive standpoint prevailing in the legal theory of the Republic of Serbia is that the term franchise should not be used to denote the subject matter of the franchise agreement, as franchise is solely the institute of the Insurance Law (Vasiljević, 2001, p. 617-618). With regard to the opinion that franchise is solely the institute of the Insurance $\mathrm{Law}^{8}$ and that the use of the term franchise for the subject matter of the agreement would be confusing, we consider such an opinion unjustified. We think that the term would not cause confusion in the professional circles and business practice since it is known what franchise refers to in the franchising agreement and what it refers to in the Insurance Law. Nevertheless, while legal theory might give rise to some confusion over the use of the term franchise, it would generally be of limited theoretical character. In our opinion, this attitude is justified as development of business practice in the autonomous commercial law inevitably influences the evolutionary development of legal theory.

Registration - The novelty in regulation of franchise agreements is the agreement registration system. Provisions of the Draft stipulate that the franchising agreement, as well as amendment, addenda, registration and termination thereof should be registered in the Registry of the Intellectual Property Office pursuant to the special law (DCCRS, art. 1262, para. 2). It obliges both the franchisor and the franchisee to carry out the registration. The question that arises is whether the entry in the registry is for a constitutive or a recording purpose. We believe that the editor's position is that the registration of agreements is primarily for informative purposes. We think that the entry in the registry should not have a recording (informative) effect, but a constitutive one. We also think that the competent authority must monitor compliance with the formal and material terms of the agreement stipulated by the provisions of the future Antitrust Code and Law (Antitrust Law-AL, Official Gazette of the

\footnotetext{
${ }^{8}$ By entering into insurance agreement by and between the insurer and the insured, it can be stipulated that the insured shall bear a part of damage if an insured event occurs, whereby a part of damage borne by the insured or the amount stipulated by the agreement charged to the insured is called franchise. The franchise can be integral or deductible. The integral franchise is a type of franchise in which damages up to a certain amount are not compensated, and if the amount of damages exceeds the amount of the franchise, the damage is compensated in full as if the franchise has not been contracted. The deductible franchise is a type of franchise in which the determined amount is always deducted, i.e. if the damage is less than the established franchise, it shall not be compensated and if it exceeds the franchise, the insured shall be paid only the difference between the franchise amount and the amount of the determined damage.
} 
RS, no.51/2009 and 95/2013). Such an attitude originates from the fact that the competent authority should monitor whether the indicated terms have been met prior to the entry in the registry because freedom of competition may be influenced by the agreement, due to the fact that lack of business practice in the Republic of Serbia may be the reason for the franchising agreement to become a means of achieving the silent monopoly in the market.

No matter whether or not the agreement is registered, legal relations between the contracting parties exist and are obliging upon both the franchisor and the franchisee (registration does not imply validity of the agreement). In the circumstances when a damage is inflicted upon a conscientious third party, and the agreement is not registered, it is stipulated that the franchisor shall be held responsible due to the failure to meet the obligation of registering the agreement with the registry. Our position is that the franchisee shall also be held responsible for the damage inflicted on the conscientious third party, as it has also been obliged to register the agreement with the registry. There is no possibility that a conscientious third party may be denied compensation for incurred damage, on the pretext that the obligation to enter the contract in the registry is a contractual obligation of either the franchisor or the franchisee. In these circumstances, only the joint and several liability of the franchisor and the franchisee provides full legal protection to a conscientious third party. The conscientious third party is aware that if damage is inflicted, both the franchisor and the franchisee shall be jointly liable, even if the agreement has not been registered.

Sub-franchising - Provisions of the Draft also stipulate the institute of sub-franchise. The franchisee is entitled to transfer the rights transferred to it pursuant to the franchising agreement to selected third parties and also to provide the services of training, supporting, controlling and monitoring based on entering into the sub-franchise agreement, all aimed at expanding the franchising network in a precisely determined territory. The franchisee needs the franchisor's consent to enter into an individual sub-franchising agreement. If it is not indicated by the agreement whether it is exclusive or non-exclusive right of the franchisee to enter into sub-franchising agreements, it is considered an exclusive right to enter into sub-franchising agreement in a certain territory (DCCRS, art. 1263).

The editor provides for the separation of legal relations from the agreement, or unless stipulated otherwise by the contracting parties to the franchise agreement, the sub-franchising agreement creates no legal relation between the franchisor from the franchising agreement and the sub-franchisee from the sub-franchising agreement (DCCRS, art. 1264). Provisions related to the franchising agreement shall also be applicable accordingly to the subfranchising agreement unless otherwise arising from the nature of the subfranchise agreement or the will of the contracting parties (DCCRS, art. 1267). However, though the separation of legal relations between the franchisor and the sub-franchisee exists, the franchisor may, in order to collect its receivables from the franchisee, request directly from the sub-franchisee payment the 
amount it owed to the sub-franchisor from the sub-franchising agreement (DCCRS, art. 1265). Notwithstanding the separation of legal relations between the franchisor and the sub-franchisee from the sub-franchising agreement, the franchisee shall bear subsidiary liability for damage inflicted on the franchisor by the actions of the sub-franchisee, unless stipulated otherwise by the franchising agreement (DCCRS, art. 1264).

The provisions of the Draft stipulate the legal fate of the subfranchising agreement. The term of the sub-franchising agreement cannot be established longer than the term of the franchising agreement. The editor accepts the principle of automatic termination of the agreement, providing that the nullification, termination and cancellation of the franchising agreement shall lead to the nullification, termination and cancellation of the subfranchising agreement. Contemporary business practice tends toward a tripartite relationship, ${ }^{9}$ and following this position, the editor provides that unless the parties to the franchising agreement concluded for a limited period otherwise provide, the rights and obligations of the sub-franchisor (which is the recipient of the franchise agreement) should be transferred to the franchisor upon termination of the sub-franchising agreement (DCCRS, art. 1266).

Responsibility of the franchisor for the content of the transferred rights - Stipulating the responsibility of the franchisor for the content of the transferred rights and the information provided is of exceptional importance for independent business operations of the franchisee. ${ }^{10}$ The franchisor as the owner or holder of the rights and authorizations it transfers to the franchisee is responsible for their existence and content, and also for the disclosures it provides to the franchisee when engaging and operating in the franchising system (DCCRS, art. 1276, para. 1). The provisions of the Draft stipulate that in the indicated case the franchisee shall be entitled to unilateral termination of the agreement or to the proportional reduction of royalty (DCCRS, art. 1276, para. 2). In each of these cases, the franchisee shall also acquire the right to compensation for the damage inflicted upon because of non-existence or inappropriate content of these rights and authorisations, as well as due to the breach of the franchisor's obligations that are important for their use (DCCRS, art. 1276, para. 3). It should be noted that the franchisee shall decide what happens to the franchise agreement based only on the economic viability of

\footnotetext{
${ }^{9}$ The opportunity for a sub-franchisee from the sub-franchise agreement to acquire the legal status of the franchisee is significant, on the one hand, for the franchisor, as it can be shown that the sub-franchisee is economically viable, while, on the other hand, the sub-franchisee may continue to operate within the franchise network and thus gain profit by acquiring the legal status of the franchisee.

${ }^{10}$ The most common basis for termination of agreement in judicial practice of the economies with developed franchising business operations is due to misapprehension on the part of a franchisee, which results from provision of incorrect or incomplete information and transferred rights.
} 
business operations, even though the franchisor provided incorrect or incomplete information or transferred incomplete rights.

In addition to the responsibility of the franchisor to the franchisee, the editor also provides for the franchisor's subsidiary responsibility to a third party. The franchisor responds as a subsidiary to the requests of a third party to the franchisee, in case of deficiencies in: a) quality of goods or b) services rendered, sold or rendered exclusively by the franchisee. The DCCRS provisions, in addition to subsidiary liability, and for the sake of legal certainty of third parties, provide for joint and several liability of the franchisor. Joint and several liability of the franchisor and the franchisee exist in case of deficiencies in the quality of goods manufactured by or the supplier of which is determined by the franchisor (DCCRS, art. 1276, para. 4-5).

Pre-contractual disclosure - The franchisor is obliged to submit to any potential franchisee a document containing pre-contractual disclosure information. The pre-contractual disclosure document must be in writing, in an official language used at the place of the potential franchisee's seat. The document must be submitted at least 20 days before entering into the franchise agreement or before payment of any fee. The potential franchisee is obliged to confirm in writing the receipt of the pre-contractual disclosure document. The potential franchisee cannot waive the right to submit a pre-contractual disclosure document in the negotiation phase. The exception for the franchisor not being obliged to submit the pre-contractual disclosure document is in the circumstances when: a) the franchisee is leasing an existing franchising agreement to a third party and b) in the case of renewal or extension of already concluded franchise agreement, without any significant changes in both cases.

A significant step forward is the stipulation of the content of the disclosure document. The provisions of the DCCRS provide that the precontractual disclosure document comprises: a) an excerpt from the proposed franchising agreement and b) a business disclosure document (information on the business entity and the franchisor's experience, the elements of the franchising system and data on the franchise network).

The editor of the DCCRS assumes that the data contained in the precontractual disclosure document has to be true, updated and of crucial importance for the franchisee when deciding on entering the franchising business system. An excerpt from the proposed franchising agreement must include the following information: 1) the type, scope and duration of protection of exclusive rights: 2) the term of the agreement and conditions for extension, renewal of transfer of the agreement to a third party; 3 ) the program, duration and costs of the training; 4) the amount, term, method of calculation and payment of the initial and royalty fee; 5) joint liabilities of the franchisor and the franchisee and consequences of failure to settle or irregular settlement of contractual obligations; 6) conditions under which the franchisor and the franchisee is entitled terminate the agreement and the consequences of 
termination; 7) limitations of the franchisee in terms of the territory, consumers and also of sales of goods and provision of services and 8) competition ban throughout the term and after termination of the agreement (DCCRS, art. 1270, para. 3).

In addition to determining the content of the excerpt, the Draft also stipulates the content of the business disclosure document. The business disclosure document must contain the data on: a) the business entity of the franchisor (corporate data), b) the franchising business system and c) franchising network (DCCRS, art. 1270, para. 4). The significance of the indicated provision lays in the fact that it leaves no space for the franchisor to act in a feudalistic manner when presenting the franchising network, thus providing legal certainty to the franchisee that it shall be informed about all elements of the franchising business operations.

Following the contemporary trends in the field of pre-contractual data disclosure, provisions of the Draft stipulate the consequences of failing to meet the pre-contractual disclosure obligation. If the franchisor fails to meet the obligation of pre-contractual disclosure, and also if the pre-contractual disclosure document does not contain true and updated data, the franchisee acquires the right to annul the franchising agreement within two years from the date of entering into the agreement, provided it can be proven that the agreement would not have been entered into had the franchisor met its obligation of pre-contractual disclosure. Likewise, if the franchisor fails to enter in the pre-contractual disclosure document any mandatory element related to the content of the franchising agreement or the data is presented incorrectly, the franchisee shall acquire the right to request annulment of the specific agreement provision that the notice should have referred to, within two years from the date of entering into the franchise agreement (DCCRS, Article 1271). Abiding by the principle of legal certainty, the editor stipulates that in case of breach of the pre-contractual disclosure obligation, the franchisee shall be entitled to compensation of damages inflicted on it by such a failure (DCCRS, Article 1271, para. 3).

Goodwill - The DCCRS in Article 1289 and Article 1294 mentions goodwill without further specifying its term or explaining what it represents. It is precisely because of the editor's lay opinion that it is an institute that should be known to both contracting parties and judicial practice, ${ }^{11}$ and which is unknown in the law of the Republic of Serbia, that we consider it necessary to elaborate more on the concept and content of goodwill.

According to the legal theory, goodwill is defined as "... a boon and benefit from a good name, reputation and affiliation of a business. It is an attractive force bringing customers. This is what distinguishes a previously established business from a new business at the very beginning. Goodwill of a

\footnotetext{
${ }^{11}$ In terms of standardisation of goodwill in the Draft, it is a legal implant unknown to the legal system in the Republic of Serbia. The editor has taken over the institute and as such incorporated it in the DCCRS without further details on what it represents.
} 
business must originate from a certain centre or source. No matter how widespread or fragmented its impact may be, goodwill has no influence if it does not have sufficient attraction power to direct customers to the source from which it originates" (Mendelshon, 2004, p. 210).

In business practice and legal theory, goodwill and reputation are often considered synonyms. Although these are seemingly similar concepts, they are not synonyms, they differ substantively. (Banerjee, 2006, p. 274-279). Reputation is important in the sense that the public, or a sufficient portion of the public, recognises the business the goodwill refers to (Mendelshon, 2004, p. 211). The judicial practice played a rather significant role in determination of the distinction between goodwill and reputation. Of importance is judgment in 1984, Anhesuer-BuSch. Inc v Budejovicky Budvar [1984] FSR 413. The plaintiff of the brewery (Budweiser), tried to limit sales of beer in England, which was made at the defendant's brewery in the then Czechoslovakia (even though the name of the beer originated therefrom). At the time of the claim, the defendant's beer was known in England thanks to advertising on TV, except that beer was available in the US military bases only, i.e. though it was advertised and well known it was not commercially available. The court concluded that though the defendant's beer was well known and reputable since it was not available to the public, no goodwill aroused during the trade that it could as such be protected from plagiarism i.e. pursuant to such judgement, it was concluded that regardless of the fact that the franchisor's product enjoyed a good reputation, i.e. franchise network enjoyed a significant reputation, there was very little chance that goodwill would be protected until a trade was established in which the product/products or service/services would be available to broad public. ${ }^{\mathbf{1 2}}$ The level of business development in the target market is a condition for the existence of goodwill. If the level of business development is poor, or in the preparatory phase, it is not sufficient for development of goodwill which as such would enjoy legal protection against plagiarism. Only the level of business development at which a product or a service known to a wide audience can influence creation of conditions necessary for legal protection of goodwill. The level of business operations that may be necessary to create goodwill with a possibility of protection depends on the nature and range of related business activities (Mendelshon, 2004, p. 211).

Legal protection of goodwill is limited in territory. The territorial limitation of legal protection means that if goodwill is recognisable and enjoys legal protection in a certain territory (within a certain market), it will enjoy the same legal protection from plagiarism in another territory. However, with the development of electronic media, and the Internet, the process of creating global and regional market for a certain product or service becomes recognisable in the market and such goodwill gains in importance, with a

\footnotetext{
${ }^{12}$ Anhesuer-BuSch. Inc v Budejovicky Budvar [1984] FSR 413. (2021, September 29). Retrieved from https://swarb.co.uk/anheuser-busch-v-budejovicky-budvar-ca-1984/
} 
possibility of legal protection. Although it takes several years for goodwill to develop in a certain market, it is enough that certain products and services are present within a targeted market (that they are subject of trade - business operations in the particular market), the Franchisor shall automatically enjoy legal protection from goodwill plagiarism. In the case Sheraton Corp of America v Sheraton Motels Ltd. [1964] RPC 202, the court ruled that even though the plaintiff did not own hotels in the territory of England, but did own them in other countries, the level or - degree of commercial activity (bookings) through the agency (the plaintiff's own agency and agents' agencies) was enough for the existence of goodwill and its legal protection. ${ }^{13}$

Reputation that is so substantially different from goodwill affects the Franchisor's ability to enjoy legal protection against plagiarism. The higher the franchisor's and franchise network's reputation, global or regional, the lower the level of business development in the target market, which is necessary for the court to conclude that there is goodwill that can enjoy legal protection (Mendelshon, 2004, p. 212). Otherwise, the lower the business reputation of the franchisor and the franchising network in the market, the degree of business development within the market is a benchmark for the court determine whether there is goodwill and whether it can enjoy legal protection.

In terms of franchising business operations, there are two types of goodwill: 1) goodwill of the franchisor and 2) goodwill reflecting the value of business operations of the franchisee. „Goodwill of the franchisor is common for the entire franchising network, and originates from brands, trade names, systems, etc. This goodwill's feature is that it is the essence of rights, i.e. it is one of a set of licensed rights within the franchising package of rights that the franchisor assigns to the franchisee" (Mendelshon, 2004, p. 212). The franchising agreement indicates that goodwill as an intellectual right belongs to the franchisor, with the aim of avoiding arbitrary interpretation of the franchisee to whom the goodwill belongs. Unlike the franchisor's goodwill, the franchisee's goodwill basically reflects the value of its business operations that it achieves while it operates independently within the franchise network. Whatever the reason for termination of the franchise agreement, except for termination due to default, the franchisee contributes to significant increase in the franchisor's business volume and raises the value and reputation of the business network, and the franchisor continues to achieve significant benefits after the termination of the agreement, is entitled to compensation for increased goodwill (DCCRS, Article 1294, para. 4). Goodwill of the franchisee is nothing more than an accounting convention which reflects the fact that the franchisee's business operations may be more valuable for a customer than net asset value. It should be noted that this type of goodwill is of no significance in plagiarism lawsuit (Mendelshon, 2004, p. 212).

\footnotetext{
${ }^{13}$ Sheraton Corp of America v Sheraton Motels Ltd. [1964] RPC 202. (2021, September 30). Retrieved from https://swarb.co.uk/sheraton-corporation-of-america-v-sheratonmotels-ltd-chd-1964/
} 


\section{Conclusion}

Like any concluding consideration relating to some of the modern autonomous commercial law treaties that are the product of contemporary Anglo-American business practice, the question of their legal regulation is being raised in countries that are unknown to legal and case law. The regulation of the franchising agreement is incomplete in the Republic of Serbia, and the legal acts whose provisions can be indirectly applied to the franchising agreement do not provide the parties with legal certainty. An aggravating circumstance is the occurance of optional implementation of acts adopted by the European Commission.

The lack of legal certainty should also be seen from the point of view that the current positive law does not know the instruments to protect the franchisee from possible misuse of the franchisor as economically dominant contracting party. What is a dilemma in the legal standardization of franchising is whether a law should be enacted that would regulate: a) the legal relations of the parties or b) the substance of the pre-contractual disclosure of information (disclosure law). In view of the legal acts of countries with developed franchise business, we are of the opinion that a law should be enacted that would regulate the substance of disclosure law, while contractual relations would be regulated by positive legal acts. Adopting a law on pre-contractual disclosure creates a legal environment that guarantees the legal security of the franchisee. Also, underdeveloped case law is one of the crucial reasons for the adoption of the law on pre-contractual disclosure.

Nevertheless, regardless of the views, and the fact that we have many objections to the legal regulation, the prediction in the Draft Civil Code of the Republic of Serbia is a significant step towards opening a legal debate on the future standardization of franchising agreement in the Republic of Serbia.

\section{Reference list}

Antitrust Law, Official Gazette of the RS, no.51/2009 and 95/2013.

Banerjee, S. (2006). „Transborder Reputation”, Journal of Intellectual Property Rights. 11(4).

Blair, D. R. \&, Lafontaine, F. (2005). The Economics of Franchising, Cambridge.

Draft Civil Code of the Republic of Serbia - DCCRS.

European Code of Ethics for Franchising. Retrieved September 29, 2021, https://franchising.eu/franchise-guide/26/the-european-code-of-ethicsfor-franchising/

Emerson, W. R. (1990). „Franchising and the Collective Rights of Franchisees", Vanderbilt Law Review, Vol. 43:1503.

Jović, M. (1990). Franchising u praksi, istine $i$ zablude, Kooperacija (franšizing) uslov opstanka malih privrednika i velike kooperacije, Zbornik radova sa sabora malih privrednika, [Franchising in practice, truths and misconceptions, Cooperation (franchising) a condition for 
the survival of small businesses and large cooperation, Proceedings of the Congress of Small Businessmen]. Vrnjačka Banja.

Kapor, V. \& Carić, S. (2000). Ugovori robnog prometa [Commodity contracts] 10en ed, Novi Sad: Center for Business Consulting.

Law on Contract and Torts, Official Gazette of SFRY, no. 29/78, 39/85, 45/89 - Decision of the Constitutional Court of Yugoslavia and 57/89, Official Gazette of SFRY, no. 31/93, 22/99, 23/99, 35/99, 44/99 and Official Gazette of Serbia and Montenegro, no. 1/2003 - Constitutional Charter.

Mendelsohn, M. (2004). Franchising law, (2nd ed.). Richmond Law \& Tax Ltd.

Miljković, S. (2018). Pravni odnosi kod ugovora o franšizingu [Legal relations in franchising agreements]. Kosovska Mitrovica: Faculty of Law University of Pristina in Kosovska Mitrovica.

Mlikotin-Tomić, D. (1986). Ugovor o franchisingu [Franchising agreement]. Zagreb: Informator.

„Regulation on Agreements between Market Participants Operating at Different Levels of Production or Distribution which are Exempt from Prohibition", Official Gazette of the Republic of Serbia, no. 11/2010.

Sautereau, G. (1992). An overview of Franchising in France, Franchising in Europe, London.

Vasiljević, M. (2001). Poslovno pravo [Business Law]. Belgrade: Faculty of Law University of Belgrade.

Zlatković, Ž. (1999). Франшизинг [Franchising]. Niš.

\section{Case law}

Anhesuer-BuSch. Inc v Budejovicky Budvar [1984] FSR 413. (2021, September 29). Retrieved from https://swarb.co.uk/anheuser-busch-vbudejovicky-budvar-ca-1984/

Sheraton Corp of America v Sheraton Motels Ltd. [1964] RPC 202. (2021, September 30). Retrieved from https://swarb.co.uk/sheratoncorporation-of-america-v-sheraton-motels-ltd-chd-1964/

\section{Internet domains}

(2021, September 25). Retrieved from https://www.statista.com/statistics/190313/estimated-number-of-usfranchise-establishments-since-2007/

(2021, September 27). Retrieved from https://www.franchisefff.com/franchise/les-chiffres-cles

(2021, September 27). Retrieved from https://en.franchiseverband.com/german-market

(2021, September 27). Retrieved from https://franchising.rs/clanak/1698/trziste-fransiza-u-srbiji-raste/

(2021, September 27). Retrieved from https://franchising.rs/clanak/1699/najvise-fransiznih-sistema-sad/ 